\title{
Consecutive Three-Component Synthesis of Donor-Substituted Merocyanines by a One-Pot Suzuki-Knoevenagel Condensation Sequence
}

\author{
Tim Meyer ${ }^{\mathbf{a}}$ \\ Thomas J. J. Müller*a (D) \\ ${ }^{a}$ Institut für Organische Chemie und Makromolekulare Chemie, Heinrich-Heine- \\ Universität Düsseldorf, Universitätsstrasse 1, D-40225 Düsseldorf, Germany \\ Thomas]J.Mueller@hhu.de
}

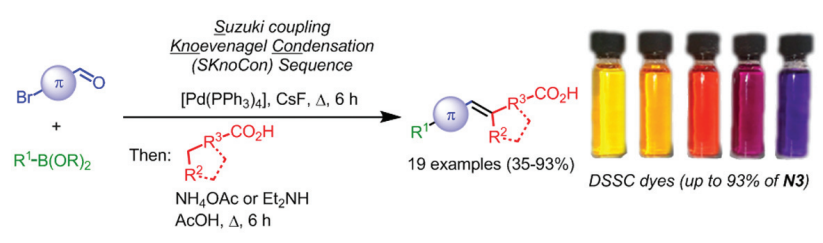

a half decades, MCRs have consequently been developed in the sense of diversity-oriented syntheses of chromophores, fluorophores, and redox-active molecules. ${ }^{8,9}$ Most fruitfully, the chromogenic approach leads to the formation of the functional chromophore by virtue of the employed MCR.

Donor heterocycles, ${ }^{10}$ such as phenothiazines and carbazoles, are particularly interesting due to their pronounced reversible oxidation potentials, electro- and photochromicity, ${ }^{11}$ and luminescence, ${ }^{12}$ electronic features that qualify (oligo)phenothiazines as donors in donoracceptor conjugates with photoinduced electron transfer characteristics, ${ }^{13}$ as hole transport materials, ${ }^{14}$ and for applications in mesoporous organosilica hybrid materials. ${ }^{15}$

From various de novo syntheses of luminescent heterocycles and push-pull systems ${ }^{8,9}$ and studies on excited-state properties of phenothiazinyl-based merocyanines ${ }^{12 a}$ and their DSSC characteristics, ${ }^{16}$ we reasoned that a general one-pot synthesis of merocyanine-type donor-donor-acceptor (Do-Do-Acc) dyes for DSSCs can be envisioned in the sense of a three-component Suzuki-Knoevenagel condensation (SuKnoCon) sequence. To our surprise, the concatenation of Suzuki arylation and Knoevenagel condensation in a one-pot process for the synthesis of functional dyes, which would be extremely useful, has not been reported to date. According to this concept, an auxiliary donor, a donor, and an acceptor with carboxylic acid functionality for ligation to $\mathrm{TiO}_{2}$ should be assembled to the functional DSSC chromophore in a consecutive MCR fashion (Scheme 1).

Here, we communicate our first findings on this straightforward synthetic approach, its variability by virtue of three points of diversity, and representative electronic properties (absorption, emission, oxidation potential, and DSSC behavior) of the obtained chromophore library.

\section{Results and Discussion}

Recently we could show that merocyanines containing 7-substituted $10 \mathrm{H}$-phenothiazin-3-yl moieties as a donor fragment are readily synthesized from the corresponding carbaldehyde by aldol condensation under mild reaction 


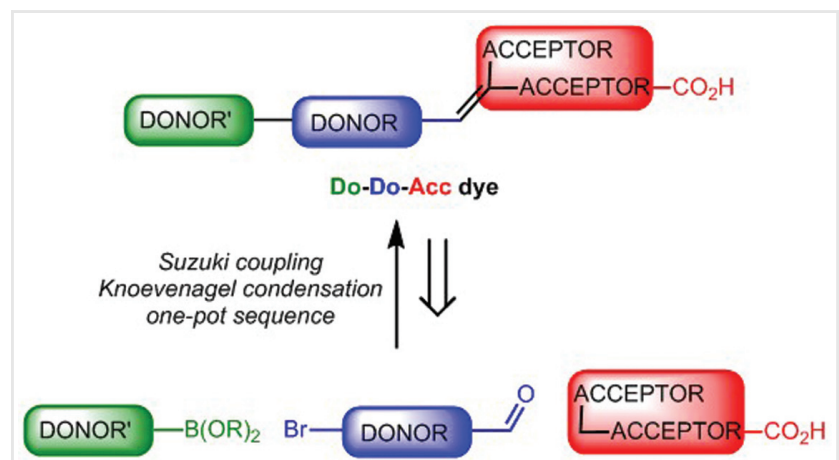

Scheme 1 Retrosynthetic analysis and consecutive three-component synthetic concept of Do-Do-Acc DSSC dyes.

conditions. ${ }^{12 a, 16 c}$ In turn the 7-substituted phenothiazinyl carbaldehydes were accessed from 7-bromo derivatives as ultimate precursors. Inspired by Suzuki-aldol cascade processes, ${ }^{17}$ we therefore reasoned that the mildly basic reaction conditions of Suzuki arylations might be excellently suited for introducing electron-rich conjugated substituents and condensations with methylene-active acceptor moieties might be efficiently conducted in a consecutive one-pot process.

Based on our previous experience in the Suzuki coupling of bromoaldehydes and Knoevenagel condensations of the resulting aldehydes in a stepwise fashion, ${ }^{12 a, 16 c}$ we preselected suitable Pd catalysts and bases for the Suzuki reaction as well as piperidine or ammonium acetate as an organocatalyst in the terminal Knoevenagel condensation for concatenating the steps to a consecutive three-component process. As a model reaction, the formation of dye $\mathbf{4 a}$ from p-tolyl boronic acid (1a), 4-bromobenzaldehyde (2a) as a structurally simple bifunctional electrophile, and $\mathrm{N}$-methyl rhodamine (3a) were employed for establishing the SuKnoCon sequence (Scheme 2, Table 1). The conversion was monitored by TLC and the isolated yields obtained under identical workup conditions were considered as a semiquantitative measure in this optimization study.

Although several other Pd catalysts were prescreened, it turned out that $\mathrm{Pd}\left(\mathrm{PPh}_{3}\right)_{4}$ in combination with $\mathrm{Cs}_{2} \mathrm{CO}_{3}$ or $\mathrm{CsF}$ as bases in the Suzuki reaction not only gave consistently high yields in the sequence but also allowed for omitting water as a cosolvent in the Suzuki reaction (Table 1, entries 3 and 6). Ammonium acetate proved to be superior over piperidine (acetate), a classical Knoevenagel

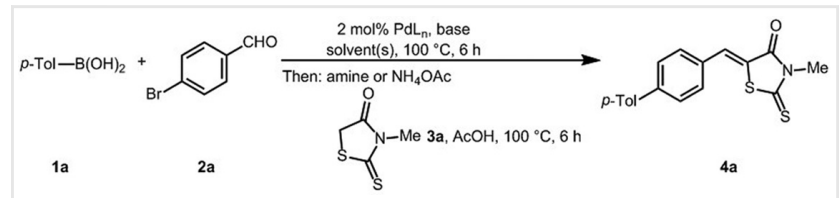

Scheme 2 Optimization of the three-component Suzuki-Knoevenagel condensation (SuKnoCon) synthesis of merocyanine $\mathbf{4 a}$.
Table 1 Optimization of the one-pot synthesis of merocyanine 4 a

\begin{tabular}{llllll}
\hline Entry & $\mathrm{Pd}$ catalyst & Base & Solvent & $\begin{array}{l}\text { Amine } \\
\text { catalyst }\end{array}$ & $\begin{array}{l}\text { Merocyanine } \\
\mathbf{4 a} \mathbf{a}^{\mathrm{a}}\end{array}$ \\
\hline 1 & $\mathrm{Pd}(\mathrm{OAc})_{2} / \mathrm{PPh}_{3}$ & $\mathrm{~K}_{2} \mathrm{CO}_{3}$ & $\mathrm{H}_{2} \mathrm{O} / \mathrm{DME}$ & $\mathrm{NH}_{4} \mathrm{OAc}$ & $81 \%$ \\
2 & $\mathrm{Pd}\left(\mathrm{PPh}_{3}\right)_{4}$ & $\mathrm{~K}_{2} \mathrm{CO}_{3}$ & $\mathrm{H}_{2} \mathrm{O} / \mathrm{DME}$ & $\mathrm{NH}_{4} \mathrm{OAc}$ & $88 \% \mathrm{c}$ \\
3 & $\mathrm{Pd}\left(\mathrm{PPh}_{3}\right)_{4}$ & $\mathrm{Cs}_{2} \mathrm{CO}_{3}$ & 1 1,4-Dioxane & $\mathrm{NH}_{4} \mathrm{OAc}$ & $85 \%$ \\
4 & $\mathrm{Pd}\left(\mathrm{PPh}_{3}\right)_{4}$ & $\mathrm{~K}_{2} \mathrm{CO}_{3}$ & 1,4 -Dioxane & Piperidine & $68 \%$ \\
5 & $\mathrm{Pd}\left(\mathrm{PPh}_{3}\right)_{4}$ & $\mathrm{CsOAc}$ & 1,4-Dioxane & - & $79 \%$ \\
6 & $\mathrm{Pd}\left(\mathrm{PPh}_{3}\right)_{4}$ & $\mathrm{CsF}$ & 1,4-Dioxane & $\mathrm{NH}_{4} \mathrm{OAc}$ & $94 \%$ \\
\hline
\end{tabular}

a Yield after chromatography on silica gel.

bThe Suzuki reaction proceeds with $92 \%$, if the coupling product is isolated

'The Suzuki reaction proceeds with $98 \%$, if the coupling product is isolated.

${ }^{\mathrm{d}}$ The Suzuki reaction proceeds with $89 \%$, if the coupling product is isolated.

${ }^{\mathrm{e}}$ The Suzuki reaction proceeds with $94 \%$, if the coupling product is isolated.

condensation organocatalyst (Table 1, entries 1-3 and 6). Interestingly, CsOAc dispenses from using an additional catalyst in the condensation step, however, furnishing dye 4a in a slightly lower yield (Table 1 , entry 5). Upon transposing the conditions of entry 6 to 3-thienylboronic acid (1b) or pinacolyl 1-methylpyrazol-4-yl boronate (1c), it immediately came out that the rate of the Suzuki coupling was clearly affected by the nature of the boronic acid derivative. If isolated, the corresponding Suzuki coupling products were obtained in 95 and $65 \%$, respectively. In the consecutive SuKnoCon sequence, the corresponding dyes $\mathbf{4 b}$ and $\mathbf{4 c}$ were obtained in isolated yields of 87 and 59\%, respectively, indicating an essentially quantitative Knoevenagel step (Scheme 3).

With these conditions for the one-pot SuKnoCon sequence in hand, we set out to synthesize several Do-Do-Acc dyes 6 containing carboxylic acid functionalities in the acceptor part via variation of the boronic acid derivatives $\mathbf{1}$, the bromoaldehyde $\mathbf{2}$, and the methylene active acids $\mathbf{5}$ (Scheme 4 ). ${ }^{18}$ In addition, we also considered 7-bromo carbazole carbaldehyde as a building block, since carbazole donors also have been identified to be relevant donor constituents in DSSCs. ${ }^{19}$ The obtained dyes $\mathbf{6}$ were quite stable in the solid state and in deaerated solutions, as qualitatively assessed by leaving stoppered test tube solutions under indirect daylight in the lab for several months. This accounts for a considerable stability against air oxidation, which was a problem in the first series of phenothiazine-based dyes with pyrrolidene substituents. ${ }^{16 c}$

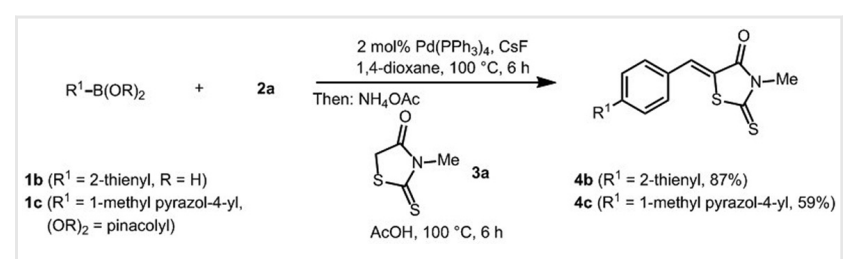

Scheme $\mathbf{3}$ Variation of boronates: SuKnoCon synthesis of the dyes $\mathbf{4 b}$ and $\mathbf{4 b}$. 


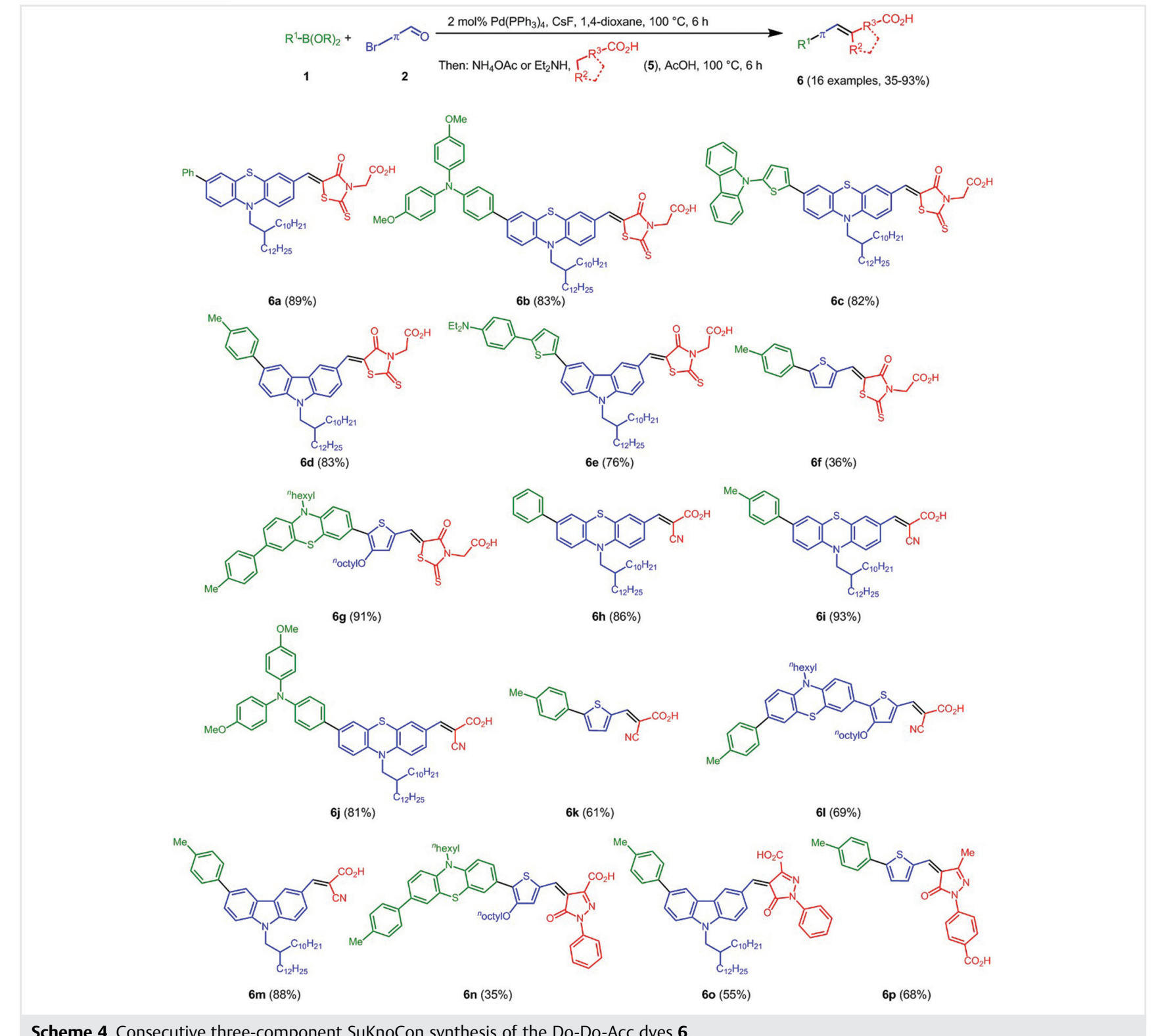

Scheme 4 Consecutive three-component SuKnoCon synthesis of the Do-Do-Acc dyes 6

In addition, upon measuring the melting behavior of the synthetic sample, neither decoloration nor decomposition was observed in the time between room temperature softening and clearing of the samples.

The sequence was illustrated by the one-pot synthesis of 16 examples in moderate to excellent yields and their structures were unambiguously assigned by NMR spectroscopy and mass spectrometry. Due to poor solubility and broad signals in the NMR for some of the carboxylic acid derivatives, structural characterization by NMR spectroscopy was performed for the methyl and TMS-methyl esters obtained by transformation of the carboxylic acids with TMS diazomethane (for details, see the Supporting Information).
The ground- and excited-state electronic properties of the merocyanines $\mathbf{6}$ were experimentally determined in dichloromethane solutions by cyclic voltammetry and absorption and emission spectroscopy (see analytical details in the Supporting Information). All merocyanine dyes 6 possess intense longest-wavelength absorption bands with maxima between 410 and $590 \mathrm{~nm}$. Out of 16 chromophores, nine merocyanines' DSSC characteristics were further investigated (Table 2) using an experimental setup similar to previously synthesized and reported phenothiazine DSSC dyes. ${ }^{16 c}$ In combination with the optical band gap $E_{0-0}$, derived from spectroscopic data, the excited-state reduction potentials $E\left(S^{+} / S^{*}\right)$ can be 
Table 2 Selected electronic properties (cyclic voltammetry, absorption, and emission) and DSSC characteristics of selected dyes 6-8

\begin{tabular}{|c|c|c|c|c|c|c|c|c|c|c|c|c|c|}
\hline \multirow[t]{2}{*}{ Entry } & \multirow[t]{2}{*}{ Dye } & \multicolumn{2}{|c|}{$\begin{array}{l}\text { Cyclic } \\
\text { voltammetry }\end{array}$} & \multirow{2}{*}{$\begin{array}{l}\text { Absorption } \\
\lambda_{\text {max,abs }}(\varepsilon)^{d}\end{array}$} & \multicolumn{2}{|l|}{ Emission } & \multirow{2}{*}{$\begin{array}{l}\begin{array}{l}\text { Excited state } \\
\text { reduction } \\
\text { potential }\end{array} \\
E\left(S^{+} / S^{*}\right) \text { vs. } \mathrm{NHE}^{\mathrm{g}}\end{array}$} & \multicolumn{6}{|c|}{$\begin{array}{l}\text { DSSC } \\
\text { characteristics }^{\text {a }}\end{array}$} \\
\hline & & $E_{0}^{0 /+7 b c}$ & $E_{0}+1 /+2 \mathrm{bc}$ & & $\lambda_{\max , e m}{ }^{\mathrm{e}}$ & $E_{0-0}{ }^{f}$ & & IPCE & $j_{\mathrm{SC}}$ & $U_{\mathrm{OC}}$ & $\mathrm{FF}$ & $x \eta$ (dye) & $\eta$ (dye) $/ \eta(8)$ \\
\hline & & {$[\mathrm{V}]$} & {$[\mathrm{V}]$} & {$[\mathrm{nm}]\left(\left[\mathrm{m}^{-1} \mathrm{~cm}^{-1}\right]\right)$} & {$[\mathrm{nm}]$} & {$[\mathrm{eV}]$} & {$[\mathrm{V}]$} & [\%] & {$\left[\mathrm{mA} \mathrm{cm}^{-2}\right]$} & {$[\mathrm{mV}]$} & & [\%] & [\%] \\
\hline 1 & $7^{[16 c]}$ & 0.69 & 0.87 & $503(18,000)$ & 688 & 2.03 & -1.15 & 24 & 4.46 & 683 & 0.60 & 1.9 & 45 \\
\hline 2 & $6 b$ & 0.65 & 0.91 & $498(22,000)$ & 643 & 2.16 & -1.31 & 25 & 4.51 & 736 & 0.61 & 2.0 & 48 \\
\hline 3 & $6 c$ & 0.86 & 1.12 & $487(28,000)$ & 646 & 2.17 & -1.11 & 16 & 2.95 & 633 & 0.58 & 1.1 & 26 \\
\hline 4 & $6 d$ & 1.26 & $-^{h}$ & $457(37,000)$ & 540 & 2.50 & -1.04 & 13 & 1.74 & 574 & 0.48 & 0.5 & 12 \\
\hline 5 & $6 g$ & 0.65 & 1.20 & $546(20,000)$ & $-i$ & $--^{\mathrm{i}}$ & $-{ }^{i}$ & 5 & 1.26 & 637 & 0.56 & 0.5 & 12 \\
\hline 6 & $6 i$ & 0.90 & 1.54 & $452(12,000)$ & 618 & 2.27 & -1.17 & 89 & 7.19 & 777 & 0.55 & 3.1 & 74 \\
\hline 7 & $6 \mathbf{j}$ & 0.65 & 0.96 & $467(15,000)$ & 620 & 2.26 & -1.41 & 93 & 6.93 & 785 & 0.56 & 3.9 & 93 \\
\hline 8 & 61 & 0.68 & 1.27 & $498(20,000)$ & 588 & 2.22 & -1.34 & 45 & 4.19 & 738 & 0.56 & 1.7 & 40 \\
\hline 9 & $6 m$ & 1.28 & $-^{\mathrm{h}}$ & $410(50,000)$ & 523 & 2.66 & -1.18 & 83 & 3.64 & 712 & 0.57 & 1.5 & 36 \\
\hline 10 & $6 n$ & 0.69 & 1.24 & $590(26,000)$ & $--^{i}$ & $--^{i}$ & $-^{i}$ & 12 & 3.41 & 645 & 0.54 & 1.2 & 29 \\
\hline 11 & 8 (N3) & $-^{\mathrm{j}}$ & $-^{\mathrm{j}}$ & $541(14,000)$ & $-^{\mathrm{j}}$ & $-^{\mathrm{j}}$ & $-^{\mathrm{j}}$ & & 11.44 & 745 & 0.49 & 4.2 & 100 \\
\hline
\end{tabular}

${ }^{\mathrm{a}}$ Recorded upon irradiation with simulated sun light AM $1.5 \mathrm{G}\left(100 \mathrm{~mW} \mathrm{~cm}{ }^{-2}\right)$ at $T=293 \mathrm{~K}$, thickness of the $\mathrm{TiO}_{2}$ film of $13 \mu \mathrm{m}$, irradiation area of $0.78 \mathrm{~cm}^{2}$.

${ }^{b}$ Recorded in $\mathrm{CH}_{2} \mathrm{Cl}_{2}, T=293 \mathrm{~K}, \mathrm{v}=100 \mathrm{mV} \mathrm{s}{ }^{-1}$, electrolyte: $\left[\mathrm{Bu}_{4} \mathrm{~N}\right]\left[\mathrm{PF}_{6}\right]$, Pt-working electrode, Pt-counter electrode, $\mathrm{Ag} / \mathrm{AgCl}$ reference electrode.

${ }^{{ }^{C} E_{0}}=\left(E_{\mathrm{pa}}+E_{\mathrm{pc}}\right) / 2$ referenced to $[\mathrm{Fc}] /[\mathrm{Fc}]^{+}=0.45 \mathrm{~V}^{22}$ or $\left[\mathrm{Cp}{ }_{2}{ }_{2} \mathrm{Fe}\right] /\left[\mathrm{Cp}{ }_{2}{ }_{2} \mathrm{Fe}\right]^{+}=-0.095 \mathrm{~V}$. ${ }^{22}$

Recorded in $\mathrm{CH}_{2} \mathrm{Cl}_{2}, T=293 \mathrm{~K}, \mathrm{C}=10^{-3} \mathrm{M}$.

${ }^{\text {e }}$ Recorded in $\mathrm{CH}_{2} \mathrm{Cl}_{2}, T=293 \mathrm{~K}, \mathrm{C}=10^{-6} \mathrm{M}$.

${ }^{f} E_{0-0}$ : the energy of the hypothetical 0-0 transition determined from the intersection of the absorption and emission bands.

gReduction potential of the excited state $E\left(\mathrm{~S}^{+} / \mathrm{S}^{*}\right)=E_{1 / 2}{ }^{0+1}-E_{0-0}$, with $E_{1 / 2}=E_{0}+0.198 \mathrm{~V}$.

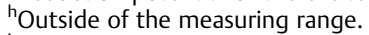

iNo detectable fluorescence.

${ }^{\mathrm{j}}$ Not determined.

estimated from the first ground-state oxidation potentials $E_{0}{ }^{0 /+1}$. A comparison of ground- and excited-state oxidation potentials with the potentials of the conduction band $(\mathrm{cb})$ of $\mathrm{TiO}_{2}\left[E^{0}\left(\mathrm{cb} \mathrm{TiO}_{2}\right)=-0.5 \mathrm{~V}\right.$ vs. NHE $]$ and the iodide/triiodide electrolyte $\left[E^{0}\left(\mathrm{I}_{3}{ }^{-} / \mathrm{I}^{-}\right)=0.54 \mathrm{~V}\right.$ vs. NHE ${ }^{16 \mathrm{c}}$ reveals that all investigated dyes $\mathbf{6}$ are well suited as sensitizers for DSSC devices based on a $\mathrm{TiO}_{2}$ photoanode and an iodide/triiodide electrolyte (Figure 1). Electron transfer from the dyes' excited states into the conduction band of $\mathrm{TiO}_{2}$ and the

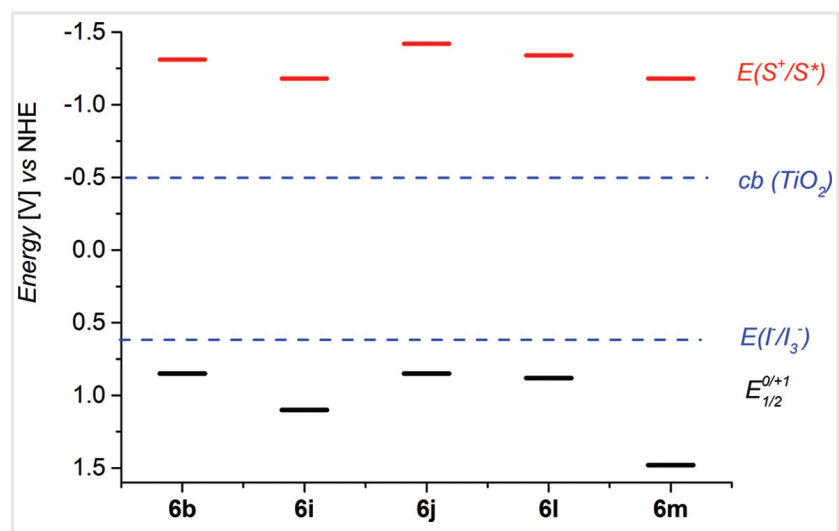

Figure 1 Schematic energy level diagram for selected dyes $6\left(E^{0}\right.$ (cb $\left.\mathrm{TiO}_{2}\right)=-0.5 \mathrm{~V}$ vs. NHE; $E^{0}\left(\mathrm{I}_{3}^{-} / \mathrm{I}^{-}\right)=0.54 \mathrm{~V}$ vs. NHE). regeneration of the oxidized dyes by the electrolyte were thermodynamically feasible.

A comparison of solar-to-electric conversion efficiencies $\eta$ (dye) on an absolute basis is difficult, since systematic mistakes might occur in the preparation of the DSSC device. To a large extent, this is dependent on the preconditioning of the $\mathrm{TiO}_{2}$ layer, immersion of the dye solutions, and subsequent treatment. Therefore, we decided, as previously reported for highly efficient indoline dyes, ${ }^{20}$ to reference our dyes to compound $8(\mathrm{~N} 3)^{21}$ by giving a relative measure $\eta($ dye $) / \eta(8)$. Under the conditions of our setup, $\eta(8)$ reproducibly gives a solar-to-electric conversion efficiency of $4.2 \%$. Because the incident photon-to-current conversion efficiencies (IPCEs) of the dyes $\mathbf{6 b}, \mathbf{6 i}, \mathbf{6 j}$, and $\mathbf{6 1}$ are relatively high and stretch over a broad region in the UV/Vis (IPCE $>20 \%$ up to $\lambda=550 \mathrm{~nm}$ ), the measured short-circuit photocurrent densities $j_{\text {SC }}$ (Table 2, Figure 2) appear in the order of value of reference $\mathbf{N} 3$.

Based on these relative solar-to-electric conversion efficiencies, previously reported phenothiazinyl-phenothiazine rhodanyl acetic acid merocyanine $\mathbf{7}^{16 \mathrm{c}}$ (Table 2 , entry 1 ) could only slightly be improved by altering the terminal auxiliary donor to a $p$-bis(anisyl)aminophenyl derivative $\mathbf{6 b}$ (Table 2, entry 2). Carbazolyl thiophene as a donor has a significantly higher oxidation potential and therefore the intramolecular reduction of the charge-separated state is hampered, resulting 

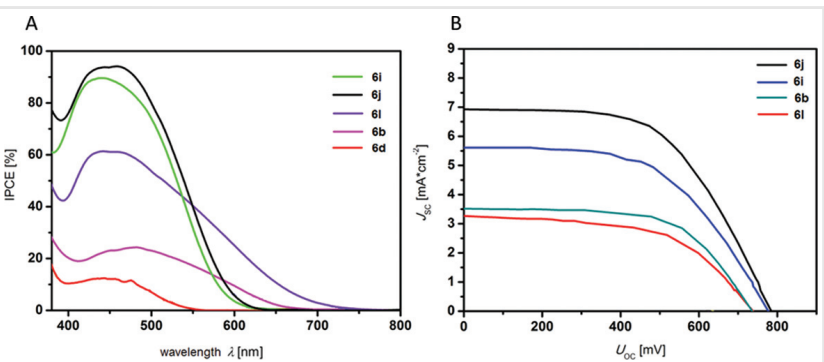

Figure 2 (A) Incident photon-to-current conversion efficiency (IPCE) of DSSCs sensitized by the selected dyes 6 (iodine/triiodide electrolyte). (B) Photocurrent density vs. voltage curves of DSSCs sensitized by the selected dyes $\mathbf{6}$ (iodine/triiodide electrolyte, under irradiation of AM 1.5 simulated sunlight, $100 \mathrm{~mW} \mathrm{~cm}^{-2}$ ).

in a lower relative solar-to-electric conversion efficiency of only $26 \%$. This trend also holds true upon replacing phenothiazine by carbazole as an internal donor for dye $\mathbf{6 d}$, resulting in a low short circuit voltage $U_{\mathrm{OC}}$ (Table 2, entry 4). Expectedly, cyano acrylic acids as acceptor moieties (Table 2, entries 6-9) give inherently higher relative solar-to-electric conversion efficiencies $\eta$ (dye) $/ \eta$ (8) than rhodanyl acetic acid dyes. However, due to the lower oxidation potentials of phenothiazines $\left[E_{0}{ }^{0 /+1}(\mathbf{6 i})=0.90 \mathrm{~V}\right.$, Table 2, entry 6] in direct comparison to carbazoles $\left[E_{0}{ }^{0 /+1}(6 \mathrm{~m})=1.28 \mathrm{~V}\right.$, Table 2, entry 9], although with similar excited-state reduction potentials $E\left(S^{+} / S^{*}\right)$, similar IPCE values, and similar fill factors (FFs), the higher short-circuit voltages $U_{\mathrm{OC}}$ and short-circuit photocurrent densities $j_{\mathrm{SC}}$ clearly correlate with the relative solar-to-electric conversion efficiencies $[\eta(\mathbf{6 i}) / \eta(8)=74 \%$, $(\eta(6 \mathrm{~m}) / \eta(\mathbf{8})=36 \%$ ]. Therefore, phenothiazinyl donors in merocyanines are clearly privileged in their DSSC performance over the more often employed carbazoles, ${ }^{4}$ as clearly supported by this investigated series of merocyanines 6 .

The IPCEs of DSSCs sensitized by the selected phenothiazine dyes $\mathbf{6}$ (Figure $2 \mathrm{~A}$ ) are in line with the absorption spectra recorded in dichloromethane solution. In the region of the longest-wavelength absorption maxima, the IPCE of $6 \mathbf{i}$ is $89(\lambda=452 \mathrm{~nm})$ and $93 \%(\lambda=467 \mathrm{~nm})$ for $\mathbf{6 j}$. This mostly transposes to photocurrent density vs. voltage curves of the investigated DSSCs (Figure 2B). Phenothiazinyl internal donor systems $\mathbf{6 i}$ and $\mathbf{6 j}$ give $\eta$ (dye) $/ \eta$ (8) values of 74 and $93 \%$ as highest values, almost reaching the value of the reference system $\mathbf{8}(\mathrm{N} 3)$ (Table 2 , entries 6 and 7 ). The auxiliary donor $R^{1}$ lowers the oxidation potential substantially to $E_{0}{ }^{0 /+1}(\mathbf{6 j})=0.65 \mathrm{~V}$ (Table 2, entry 7) and enhances the IPCE and the shortcircuit voltage $U_{\mathrm{OC}}$ and thereby the solar-to-electric conversion efficiency to $\eta \quad(\mathbf{6 j})=3.9 \% \quad\left[\begin{array}{ll}\eta & (\mathbf{6} \mathbf{j}) / \eta\end{array}\right.$ $(8)=93 \%$. Apparently, the reduction potential of the excited state $E\left(S^{+} / S^{*}\right)$ as calculated from the lowest oxidation potential, which is centered on the auxiliary donor, is particularly important for generating the chargeseparated state. In addition, the $p$-bis(anisyl)aminophenyl also beneficially matches with the DSSC setup, giving substantially high $j_{\mathrm{SC}}$ and $U_{\mathrm{OC}}$ values.

Interestingly, the comparison between the chromophores $\mathbf{6 b}$ and $\mathbf{6 l}$, rhodanyl merocyanine $\mathbf{6 b}$, and cyano acrylic acid merocyanine $\mathbf{6 1}$ with similar electronic characteristics $E_{0}{ }^{0 /+1}, \lambda_{\text {max,abs }}(\varepsilon), E\left(S^{+} / S^{*}\right)$, and even comparable short-circuit voltages $U_{\mathrm{OC}}$ clearly underlines the importance of the short-circuit photocurrent density $j_{S C}$ of the DSSC, which is significantly higher for the rhodanyl merocyanine $\mathbf{6 b}\left[j_{\mathrm{SC}}(\mathbf{6 b})=4.51 \mathrm{~mA} \mathrm{~cm}^{-2}\right]$ than for the cyano acrylic acid merocyanine $6 \mathbf{1}\left[j_{\mathrm{sc}}(\mathbf{6 l})=4.19 \mathrm{~mA} \mathrm{~cm} \mathrm{~cm}^{-2}\right]$. The slightly higher fill factor $[\mathrm{FF}(\mathbf{6 b})=0.61 ; \mathrm{FF}(\mathbf{6 1})=0.56]$ manifests the differences in the relative solar-to-electric conversion efficiencies $[\eta(\mathbf{6 b}) / \eta(\mathbf{8})=48 \%,(\eta(\mathbf{6 1}) / \eta(\mathbf{8})=40 \%]$.

An insight into the electronic structure of the relevant absorption bands of dye $\mathbf{6} \mathbf{j}$ in the visible region was obtained via quantum chemical calculations. The geometry of the electronic ground-state structure of dye $\mathbf{6 j}$ (truncated to the $N$ ethyl derivative) was optimized by a density-functional theory (DFT) calculation (B3LYP functional, 6-31G* basis set) ${ }^{23}$ and verified by frequency analyses of the local minimum. The electronic absorptions of dye $\mathbf{6} \mathbf{j}$ were calculated on the level of time-dependent DFT (TDDFT) theory employing the B3LYP functional and the $6-31 G^{*}$ basis set. ${ }^{23}$ The calculated three longest-wavelength absorption bands appear at 577 (with low oscillator strength), 477, and $365 \mathrm{~nm}$, the latter with a significantly higher oscillator strength (Figure 3), and nicely reproduce the experimental spectrum (see Table 2 , entry 7 , and Supporting Information, 4.10). Indeed, the calculated band at $577 \mathrm{~nm}$ falls into the onset of the broad merocyanine band with a maximum of $467 \mathrm{~nm}$ in the experimental spectrum. The lowest energy band with the weakest intensity at $577 \mathrm{~nm}$ represents the Franck-Condon $\mathrm{S}_{1}$ state and can be best characterized by a HOMO-LUMO transition (99\%; for details,

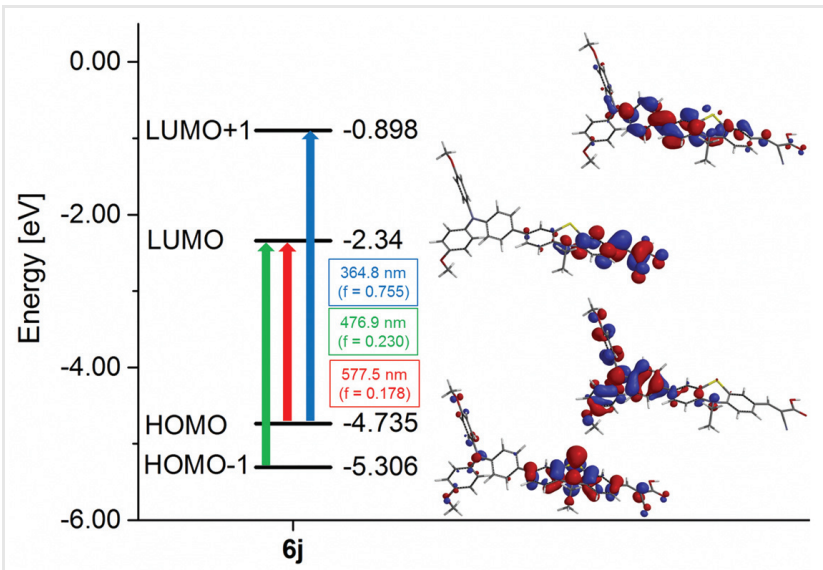

Figure 3 Selected TDDFT-computed (B3LYP 6-31G*) Kohn-Sham FMOs, absorption bands, and oscillator strengths $f$ of dye $\mathbf{6 j}$ (truncated to the $\mathrm{N}$-ethyl derivative) representing contributions of the FranckCondon absorption bands of the first three states $S_{1}, S_{2}$, and $S_{3}$. 
see the Supporting Information, Table S6). The bands at 477 and $365 \mathrm{~nm}$ correspond to $S_{2}$ and $S_{3}$ states and are represented by HOMO - 1-LUMO $\left(\lambda_{\max }=477 \mathrm{~nm}\right)$ and HOMO-LUMO $+1\left(\lambda_{\max }=365 \mathrm{~nm}\right)$ transitions. All the three states consist of considerable charge transfer character, however, with a relatively weak overlap for the HOMO-LUMO transition $\left(\mathrm{S}_{1}\right)$ in comparison to the $S_{2}$ and $S_{3}$ states. Therefore, the initially proposed concept for diversity-oriented syntheses of merocyanine-type Do-Do-Acc for enhancing DSSC characteristics is supported by both experimental and computational results.

\section{Conclusion}

Based on the modular synthetic approach to DSSC dyes employing a consecutive three-component SuKnoCon synthesis of the Do-Do-Acc conjugates, efficient DSSC dyes can be rapidly synthesized and their solar cell performance can be semi-quantitatively evaluated. In comparison to Grätzel's dye N3, some dyes investigated in this study reached almost a comparable efficiency. In addition, this one-pot concept enables for accessing a huge structural space which can be exploited for establishing reliable structure-property relationships for merocyanines, which can also be considered as suitable absorbers for $\mathrm{BHJ}$ (bulk heterojunction) solar cells. Future studies expanding the synthetic concept to more sophisticated dyes and their physical-organic treatment are currently underway.

\section{Funding Information}

This study was funded by Evonik Stiftung and Fonds der Chemischen Industrie.

\section{Acknowledgments}

The authors cordially thank the Evonik Stiftung (stipend for T.M.) and the Fonds der Chemischen Industrie for financial support.

\section{Supporting Information}

Supporting information for this article is available online at: https://doi.org/10.1055/s-0040-1702148.

\section{References}

(1) Müller, T. J. J.; Bunz, U. H. F., eds. Functional Organic Materials: Syntheses, Strategies, and Applications. Wiley-VHC: Weinheim, 2007.
(2) (a) Li, Z. R., ed. Organic Light-Emitting Materials and Devices, 2nd ed. CRC Press: Boca Raton, 2015. (b) Thejo Kalayani, N.; Dhoble, S. J. Renewable Sustainable Energy Rev. 2012, 16, 2696. (c) Park, J-S.; Chae, H.; Chung, H. K.; Lee, S. I. Semicond. Sci. Technol. 2011, 26, 034001. (d) Müllen, K.; Scherf, U., eds. Organic Light Emitting Devices: Synthesis, Properties and Applications. Wiley VCH: Weinheim, 2006.

(3) (a) Torsi, L.; Magliulo, M.; Manoli, K.; Palazzo, G. Chem. Soc. Rev. 2013, 42, 8612. (b) Kim, Y.; Bonnassieux, C-H.; Horowitz, G. IEEE Trans. Electron Devices 2014, 61, 278. (c) Kymissis, I. Organic Field Effect Transistors: Theory, Fabrication and Characterization. Springer: New York, 2009.

(4) (a) Grätzel, M. Nature 2001, 414, 338. (b) Mishra, A.; Fischer, M. K. R.; Bäuerle, P. Angew. Chem. Int. Ed. 2009, 48, 2474. (c) Clifford, J. N.; Martínez-Ferrero, E.; Viterisi, A.; Palomares, E. Chem. Soc. Rev. 2011, 40, 1635. (d) Kumavata, P. P.; Sonarb, P.; Dalal, D. S. Renewable Sustainable Energy Rev. 2017, 78, 1262.

(5) (a) Su, Y-W.; Lan, S-C.; Wei, K-H. Mater. Today 2012, 15, 554. (b) Ameri, T.; Li, N.; Brabec, C. J. Energy Environ. Sci. 2013, 6, 2390. (c) Yam, V. W. W.; Chan, M. M-Y.; Tao, C-H., eds. WOLEDs and Organic Photovoltaics. Springer-Verlag: Berlin, 2010. (d) Brabec, C.; Dyakonov, V.; Scherf, U., eds. Organic Photovoltaics. WileyVCH: Weinheim, 2008.

(6) (a) For representative reviews on MCR, see e.g. Posner GH. Chem. Rev. 1986, 86, 831.(b) Dömling, A.; Ugi, I.Angew. Chem. Int. Ed. 2000 39, 3168. (c) Bienaymé, H.; Hulme, C.; Oddon, G.; Schmitt, P. Chem. Eur. J. 2000, 6, 3321. (d) For representative monographs, see e.g. Zhu, J.; Bienaymé, H., eds. Multi-component Reactions. Wiley-VHC: Weinheim, 2005. (e) Müller, T. J. J., ed. Multicomponent Reactions, Science of Synthesis Series. Georg Thieme Verlag KG: Stuttgart, 2014. (f) Zhu, J.; Wang, Q.; Wang, M-X., eds. Multi-component Reactions in Organic Synthesis. Wiley-VHC: Weinheim, 2015.

(7) Müller, T. J. J., ed. Multicomponent Reactions 1. General Discussion and Reactions Involving a Carbonyl Compound as Electrophilic Component, Science of Synthesis Series. Georg Thieme Verlag KG: Stuttgart, 2014, 5.

(8) (a) For reviews, see Müller, T. J. J. Functional Organic Materials Syntheses, Strategies, and Applications. Müller, T. J. J.; Bunz, U. H. F., eds.; Wiley-VHC: Weinheim, 2007, 179. (b) Levi, L.; Müller, T. J. J. Chem. Soc. Rev. 2016, 45, 2825.

(9) For an account, see Müller, T. J. J.; D'Souza, D. M. Pure Appl. Chem. 2008, 80, 609 .

(10) For a review on charge carrier transporting molecular materials in devices, see e.g. Shirota, Y.; Kageyama, H. Chem. Rev. 2007, 107, 953.

(11) Zhou, G.; Pschirer, N.; Schöneboom, J. C.; Eickemeyer, F.; Baumgarten, M.; Müllen, K. Chem. Mater. 2008, 20, 1808.

(12) (a) Hauck, M.; Stolte, M.; Schönhaber, J.; Kuball, H.-G.; Müller, T. J. J. Chem. Eur. J. 2011, 17, 9984. (b) Hauck, M.; Schönhaber, J.; Zucchero, A. J.; Hardcastle, K. I.; Müller, T. J. J.; Bunz, U. H. F. J. Org. Chem. 2007, 72, 6714.

(13) (a) Bay, S.; Makhloufi, G.; Janiak, C.; Müller, T. J. J. Beilstein J. Org. Chem. 2014, 10, 1006. (b) Bay, S.; Müller, T. J. J. Z. Naturforsch., B: Chem. Sci. 2014, 69b, 541. (c) Bay, S.; Villnow, T.; Ryseck, G.; RaiConstapel, V.; Gilch, P.; Müller, T. J. J. ChemPlusChem 2013, 78, 137. (d) Bucci, N.; Müller, T. J. J. Tetrahedron Lett. 2006, 47, 8329. (e) Bucci, N.; Müller, T. J. J. Tetrahedron Lett. 2006, 47, 8323.

(14) Müller, T. J. J.; Franz, A. W., Barkschat (née Krämer) CS, Sailer, M.; Meerholz, K.; Müller, D.; Colsmann, A.; Lemmer, U. Macromol. Symp. 2010, 287, 1.

(15) Zhou, Z.; Franz, A. W.; Hartmann, M.; Seifert, A.; Müller, T. J. J.; Thiel, W. R. Chem. Mater. 2008, 20, 4986. 
(16) (a) Huang, Z-S.; Meier, H.; Cao, D. J. Mater. Chem. C 2016, 4, 2404. (b) Bodedla, G. B.; Thomas, K. R. J.; Lib, C-T.; Ho, K-C. RSC Adv. 2014, 4, 53588. (c) Meyer, T.; Ogermann, D.; Pankrath, A.; Kleinermanns, K.; Müller, T. J. J. J. Org. Chem. 2012, 77, 3704. (d) Park, S. S.; Won, Y. S.; Choi, Y. C.; Kim, J. H. Energy Fuels 2009, 23, 3732. (e) Tian, H.; Yang, X.; Chen, R.; Pan, Y.; Li, L.; Hagfeldt, A.; Sun, L. Chem. Commun. 2007, 3741.

(17) (a) Kim, J. K.; Kim, Y. H.; Nam, H. T.; Kim, B. T.; Heo, J-N. Org. Lett. 2008, 10, 3543. (b) Gruttadauria, M.; Bivona, L. A.; Lo Meo, P.; Riela, S.; Noto, R. Eur. J. Org. Chem. 2012, 2635. (c) Zhang, Z.; Zheng, J.; Du, Q.; Zhang, W.; Li, Y. Chin. J. Chem. Phys. 2012, 30, 1543. (d) Kumar, R., Richa, Andhare, N. H.; Shard, A.; Sinha, A. K. Chem. Eur. J. 2013, 19, 14798.

(18) Typical procedure for the consecutive three-component SuKnoCon of merocyanines 6 (compound $\mathbf{6 j}$ ): Aryl boronate 1e $(272 \mathrm{mg}, \quad 0.64 \mathrm{mmol})$, bromoaldehyde $2 \mathbf{b}$ (339 mg, $0.53 \mathrm{mmol}$ ), cesium fluoride (256 mg, $1.70 \mathrm{mmol}$ ), and tetrakis (triphenyl-phosphane)palladium( 0$) \quad(18 \mathrm{mg}, 15 \mu \mathrm{mol})$ were placed in a Schlenk flask with a magnetic stir bar under nitrogen and dry 1,4-dioxane ( $2.5 \mathrm{~mL}$ ) was added. The solution was heated to $100^{\circ} \mathrm{C}$ under reflux for $16 \mathrm{~h}$. After cooling to room temperature, acetic acid $(1.3 \mathrm{~mL})$, the $\mathrm{CH}$-acidic compound $\mathbf{5 b}(68 \mathrm{mg}$, $0.8 \mathrm{mmol}$ ), and ammonium acetate $(40 \mathrm{mg}, 0.5 \mathrm{mmol}$ ) were added to the reaction mixture. This mixture was heated under nitrogen to $95^{\circ} \mathrm{C}$ under reflux for $8 \mathrm{~h}$. After cooling of the dark red solutions to room temperature, the reaction mixture was diluted with dichloromethane $(20 \mathrm{~mL})$ and the organic layer was washed with distilled water until the aqueous phase did not smell like acetic acid. The combined aqueous phases were extracted with dichloromethane and the combined organic layers were dried (anhydrous magnesium sulfate) and the solvents were removed in vacuo. The residue was adsorbed on silica gel $(3.2 \mathrm{~g})$ and purified by flash chromatography on silica gel (dichloromethane - dichloromethane/methanol, 20:1). After subsequent drying under vacuo compound $\mathbf{6 j}$ (397 $\mathrm{mg}, 81 \%$ ) was obtained as an amorphous dark red solid, Mp $112-119{ }^{\circ} \mathrm{C}$. $\mathrm{R}_{f}$ (dichloromethane/methanol, $10: 1)=0.40 .{ }^{1} \mathrm{H} \mathrm{NMR}\left(300 \mathrm{MHz}\right.$, acetone- $\mathrm{d}_{6} / \mathrm{CS}_{2} 4: 1+1$ drop of TFA): $\delta 0.87\left(\mathrm{t}^{3} \mathrm{~J}=6.6 \mathrm{~Hz}, 3 \mathrm{H}\right), 0.88\left(\mathrm{t},{ }^{3} \mathrm{~J}=6.6 \mathrm{~Hz}, 3 \mathrm{H}\right), 1.19-1.51$ $(\mathrm{m}, 40 \mathrm{H}), 2.02-2.05(\mathrm{~m}, 1 \mathrm{H}), 3.78(\mathrm{~s}, 6 \mathrm{H}), 3.96\left(\mathrm{~d}^{3} \mathrm{~J}=7.1 \mathrm{~Hz}, 2 \mathrm{H}\right)$, 6.86-6.93 (m, $6 \mathrm{H}), 7.01-7.09$ (m, $4 \mathrm{H}), 7.10\left(\mathrm{~d},{ }^{3} \mathrm{~J}=8.6 \mathrm{~Hz}, 1 \mathrm{H}\right)$, $7.16\left(\mathrm{~d},{ }^{3} \mathrm{~J}=8.7 \mathrm{~Hz}, 1 \mathrm{H}\right), 7.37\left(\mathrm{~d},{ }^{4} \mathrm{~J}=2.1 \mathrm{~Hz}, 1 \mathrm{H}\right), 7.41-7.47(\mathrm{~m}, 3$ H), $7.89\left(\mathrm{~d},{ }^{4} \mathrm{~J}=2.1 \mathrm{~Hz}, 1 \mathrm{H}\right), 7.97\left(\mathrm{dd},{ }^{3} \mathrm{~J}=8.7 \mathrm{~Hz},{ }^{4} \mathrm{~J}=2.2 \mathrm{~Hz}, 1\right.$ $\mathrm{H}), 8.14(\mathrm{~s}, 1 \mathrm{H}) .{ }^{13} \mathrm{CNMR}\left(75 \mathrm{MHz}\right.$, acetone- $\mathrm{d}_{6} / \mathrm{CS}_{2} 4: 1+1$ drop of TFA): $\delta 14.5\left(\mathrm{CH}_{3}\right), 23.5\left(\mathrm{CH}_{2}\right), 26.9\left(\mathrm{CH}_{2}\right), 30.20\left(\mathrm{CH}_{2}\right), 30.23\left(\mathrm{CH}_{2}\right)$, $30.3\left(\mathrm{CH}_{2}\right), 30.42\left(\mathrm{CH}_{2}\right), 30.44\left(\mathrm{CH}_{2}\right), 30.46\left(\mathrm{CH}_{2}\right), 30.49\left(\mathrm{CH}_{2}\right)$, $30.53\left(\mathrm{CH}_{2}\right), 30.7\left(\mathrm{CH}_{2}\right), 32.0\left(\mathrm{CH}_{2}\right), 32.7\left(\mathrm{CH}_{2}\right), 35.6(\mathrm{CH}), 52.3$ $\left(\mathrm{CH}_{2}\right), 55.7\left(\mathrm{CH}_{3}\right), 100.1\left(\mathrm{C}_{\text {quat }}\right), 115.6(\mathrm{CH}), 116.95(\mathrm{CH}), 117.00$ ( $\left.\mathrm{C}_{\text {quat }}\right), 118.18(\mathrm{CH}), 121.0(\mathrm{CH}), 125.6\left(\mathrm{C}_{\text {quat }}\right), 125.7(\mathrm{CH}), 126.20$ $\left(\mathrm{C}_{\text {quat }}\right), 126.22(\mathrm{CH}), 126.8\left(\mathrm{C}_{\text {quat }}\right), 127.6(\mathrm{CH}), 127.7(\mathrm{CH}), 130.6$ (CH), 131.8 ( $\left.\mathrm{C}_{\text {quat }}\right), 132.5(\mathrm{CH}), 137.3\left(\mathrm{C}_{\text {quat }}\right), 141.4\left(\mathrm{C}_{\text {quat }}\right), 143.0$ ( $\left.\mathrm{C}_{\text {quat }}\right), 149.1$ ( $\left.\mathrm{C}_{\text {quat }}\right), 151.2\left(\mathrm{C}_{\text {quat }}\right), 153.7(\mathrm{CH}), 157.2\left(\mathrm{C}_{\text {quat }}\right), 164.0$ $\left(\mathrm{C}_{\text {quat }}\right)$. MS (MALDI-TOF) calcd. for $\left[\mathrm{C}_{60} \mathrm{H}_{75} \mathrm{~N}_{3} \mathrm{O}_{4} \mathrm{~S}\right]+$ : 933.55 ; Found: 933.6. ESI-HRMS calcd. for $\left[\mathrm{C}_{60} \mathrm{H}_{75} \mathrm{~N}_{3} \mathrm{O}_{4} \mathrm{~S}\right]{ }^{+}$: 933.5473 ; Found: 933.5472..

(19) Sathiyan, G.; Sivakumar, E. K. T.; Ganesamoorthy, R.; Thangamuthu, R.; Sakthivel, P. Tetrahedron Lett. 2016, 57, 243.

(20) Horiuchi, T.; Miura, H.; Uchida, S. Chem. Commun. 2003, 24, 3036.

(21) (a) Nazeeruddin, M. K.; Kay, A.; Rodicio, L.; Humpbry-Baker, R.; Müller, E.; Liska, P.; Vlachopoulos, N.; Grätzel, M.J. Am. Chem. Soc. 1993, 115, 6382. (b) Grätzel, M. J. Photochem. Photobiol., A 2004, $164,3$.

(22) Zanello, P. Ferrocenes. Togni, A.; Hayashi, T., eds.; Wiley VHC: Weinheim, 1995, 317.

(23) As implemented in SPARTAN '16 Version 2.0.7. Wavefunction Inc.: Irvine, CA (USA), 2017. 